\title{
THE TAMING OF SPACE IN RECOVERED TERRITORIES. THE PARTICIPATORY ASPECTS OF BIENNALE OF SPATIAL FORMS IN ELBLĄG AND VISUAL ARTS SYMPOSIUM WROCŁAW'70
}

\begin{abstract}
This article will cover a number of issues concerning artistic events indicated in the title with emphaisis on the activities or projects of the artists actively involved 'ordinary citizens,' the inhabitants of Poland's Western and Northern Territories, where Poles were resettled after 1945 , in the process of co-creation/reception of their artistic work. An attempt will be made to answer the following questions: To what extent did the en plein air events and symposia de facto realize the ideas propagated by the communist authorities in Poland? Perhaps these artworks, originally intended by their creators to enliven the public space, are now perceived from the contemporary perspective and have finally triumphed over empty communist dialectics, creating artistic value that Pierre Bourdieu could include within the scope of objectified forms of cultural capital? Did they really contribute to the cultural 'domestication' of the northern and western territories, where the dicussed events were organized? Also, last but not least: the question concerning the nature of the aforementioned participation - what was the nature of the contribution from the individual participants to the co-creation and realization of the projects?
\end{abstract}

Keywords: participation in art, art in public space, Biennale of Spatial Forms in Elbląg, Visual Arts Symposium Wrocław '70, art of Western and Northern Territories

Art in public space varies in terms of its nature and origin. Its primary distinguishing characteristics include, on the one hand, an attempt to revitalize urban space, and on the other - an endeavour to take art out of the galleries and link it to the everyday life of the city. Both of these trends that sparked my interest were initiated by the activities of the First Avant-Garde and were significant 
for many different groups, not just to the Polish artists of the 1960s and 1970s. In Great Britain, for instance, young artists from left-wing democratic circles were engaged in radical social movements that aimed to prevent the degradation of port and industrial cities. ${ }^{1}$ The work of art - an object as an output of the artist's work, in many cases ceased to play a primary role, leaving a space for reflection on social relations and on the new connections between the art recipients and the artists, who, through their actions, have created a new status of the hitherto viewers as contributors to the artistic work. ${ }^{2}$ The relativity of art and the fact that art has approached the sphere of inter-human relations as described by Nicolas Bourriaud with regard to the works of several artists active in the 1990s, are aspects that were already clearly present in the activities of 1960s' artists involved in the artistic events listed in the title of this article. ${ }^{3}$

Both of the events discussed below were held under the motto of the 'return' of the Western and Northern Territories to the Motherland (on the twentieth and twenty-fifth anniversary of the end of the Second World War). ${ }^{4}$ These

1 H. Taborska, Wspótczesna sztuka publiczna, Warszawa 1996, p. 99. These activities can be regarded as conscious opposition against gentrification practices. Vide: R. Glass, London. Aspects of Change, Centre for Urban Studies, University College in London, MacGibbon \& Kee, London 1964; J. Brown-Saracino, ed., The Gentrification debates, Routledge, New York 2010.

2 Cf.: J. Erbel, M. Żakowska, Sztuka w przestrzeni publicznej, in: Partycypacja. Przewodnik Krytyki Politycznej, J. Erbel, P. Sadura, eds., Warszawa 2012, p. 259. As might be expected, the factors, which had an important influence on the processes of ennoblement of the recipient and art moving out from the galleries, were the general changes in art trends, such as the emergence of happening art or conceptual art.

3 In the introduction to the Polish edition of his book, the author admitted that, already in the 1960s, many artists attempted to perform activities, which were ideologically close to the concepts described by him in Relational Aesthetics: N. Bourriaud, Estetyka relacyjna, transl. Ł. Białkowski, MOCAK, Kraków 2012, p. 14-15.

4 The aim outlined in such a way, was one of the conditions of receiving permission from the authorities and also the funding for the event. Many similar initiatives of symposial and en plein air character were organized in Poland in the 1960s and 1970s, not only in Western and Northern Territories; their outcomes, in the case of three-dimensional structures found their place in the urban public space. The most significant events, apart from those discussed in this text, were the First Symposium of Artists and Scientists in Puławy in 1966 and, a decade later, Lublin Visual Arts Meetings, 1976-1979. Vide: A. M. Leśniewska, Puławy 66. I Sympozjum Artystów Plastyków i Naukowców 2-23 sierpnia 1966, Towarzystwo Przyjaciół Puław, Puławy 2006; I. J. Kamiński, Lubelskie Spotkania Plastyczne, Krajowa Agencja Wydawnicza, Lublin 1979. The reflection of the artists on the form of the arrangement of urban space was usually related to the real space, taking the form of project ideas that included the existing architectural and urban layout. As mentioned by Marian Bogusz, this attitude by Polish artists was a particular novelty for other artists, for instance, during the Symposium of Spatial Sculpture in the Danish city of Aalborg (1967). Vide: M. Bogusz, Fragment dziennika, in: Realizacja i propozycje, [exhibition cat.] Zachęta, May 1968, Warszawa, p. 3, 6; as cited in: B. Kowalska, Bogusz - artysta i animator, Muzeum Regionalne w Pleszewie, Pleszewskie Towarzystwo Kulturalne, Pleszew 2007, p. 120. 
two artistic events are clear demarcated time points, which specifically illustrate the transitions in Polish art in those five years. The differences are striking even in terms of the format of these events. The actual outcome of the 1965 Biennale of Spatial Forms in Elbląg were several metal sculptures - the result of artists' collaboration with engineers and workers from the ZAMECH factory in Elblag, placed at various locations within the city. In turn, the projects by the participants of the Visual Arts Symposium Wrocław '70, whose ideas aimed at a criticism of visuality, shifted the center of gravity of interest from the 'object' to the 'concept,' in the majority of cases, these ideas were never realized. In both events, their participatory aspect can be strongly distinguished, but it took different forms. In Elblagg, the group of participants - the co-creators of the artworks were selected in advance - were employees of the ZAMECH factory, while only a handful of regular residents and ordinary passers-by attended. In contrast, authors of projects carried out as part of the 1970 Visual Arts Symposium wanted to engage the citizens of Wrocław not only in ephemeral activities, but they planned for a long-term interest from the residents of a given district. ${ }^{5}$ Ryszard Kluszczyński pointed to the immaterial and fleeting character of the art work, the collectivization of its creation processes and the creative activity of recipients as a set of characteristics that shaped participatory trends in happening $\operatorname{art}^{6}$ - these features were easily observed over the course of Elbląg Biennale and in the conceptual principles of the Wrocław '70 Symposium.

In this article, a number of issues will be raised concerning the artistic events listed in the title with specific consideration of the artists' undertakings that actively involved 'ordinary citizens' -residents of Poland's Western and Northern Territories, where Poles were resettled after 1945, in the process of the co-creation/reception of the work of art. In addition, an attempt will be made to answer the following questions: To what extent did the en plein air events and symposia de facto realize the ideas propagated by the communist authorities in Poland? Perhaps these artworks, originally intended by their creators to enliven public space, are now perceived from the current perspective and have finally triumphed over empty communist dialectics, creating an artistic value that Pierre Bourdieu would include within the scope of objectified forms of cultural capital?? ${ }^{7}$ Did they really contribute to the cultural 'domesti-

5 This is related, for instance, to the projects by the team of Marian Bogusz designed for Celina residential estate or to the proposal of The Auto-theatre by Oskar Hansen, described further on in the text.

R.W. Kluszczyński, Sztuka interaktywna. Od dzieła-instrumentu do interaktywnego spektaklu, Wydawnictwa Akademickie i Profesjonalne, Warszawa 2010, p. 81.

Cf.: T. Zarycki, Kapitat Kulturowy - zatożenia i perspektywy zastosowań teorii Pierre'a Bourdieu, "Psychologia Społeczna" 2009, vol. 4, no 1-2, p. 12-25. 
cation'8 of northern and western territories, where the events discussed below were organized? Also, last but not least: the question about the nature of the aforementioned participation - what was the nature of the contribution from individual participants to the co-creation and realization of projects?

Before I address the research objectives formulated as questions, I would like to make an introduction, presenting the specificity of the regions that hosted the artistic events in question, which affected both the planned and achieved outcome. The lack of cultural continuity of the territories annexed to Poland after 1945 as a result of the Yalta and Potsdam Conferences was the main reason why restoring local identity was difficult in Western and Northern Territories. The displacement of previous inhabitants and resettlement of these regions after the end of World War II diametrically changed their ethnic structure. We may also add that this structure was far from homogenous. ${ }^{9}$ The sense of impermanence was particularly common among the new settlers and it persisted for many years. This was the major cause of the new residents' reluctance to investing in the existing space and reorganizing it for themselves to make it more friendly. ${ }^{10}$. There were additional factors, as Andrzej Brencz notes, for example a belief that the economy, material culture and climate were alien. ${ }^{11}$

What is important for the artistic events described in the article is the definition of 'space.' It is essential to distinguish between the 'space' in its pure

8 My understanding of the term 'domestication' is the elimination of the sense of foreignness, temporariness or the issues with finding the local identity that troubled the new settlers in Western and Northern Territories, to which I refer later in the text.

9 And not only before World War II, but also, against the intentions of Poland's communist authorities, in the new geopolitical situation after 1945. The topic of forced migrations (I use this term after Aneta Pazik: A. Pazik, Migracje przymusowe jako instrument konsolidacji państwa narodowego $w$ XX wieku. Przypadek wysiedleń Niemców z Polski po II wojnie światowej, "Kultura i Polityka" 2013, vol. 13, p. 131-152) of people in the regions concerned, has been, especially in recent years, the subject to critical research, i.a. M. Hejger, Przeksztatcenia narodowościowe na ziemiach Zachodnich i Pótnocnych Polski w latach 1945-1959, Wydawnictwo Naukowe Akademii Pomorskiej, Słupsk 2008, but also: P. Eberhardt, Migracje polityczne na ziemiach polskich (1939-1950), Instytut Zachodni, Poznań 2010; P. Kacprzak, Dziatania organów administracji państwowej w akcji wysiedlenia $i$ wyjazdach ludności niemieckiej z Polski w 1945 roku, "Studia Lubuskie" 2010, vol. 6, p. 87-108; A. Magierska, Ziemie zachodnie i pótnocne w 1945 roku. Kształtowanie się podstaw polityki integracyjnej państwa polskiego, Książka i Wiedza, Warszawa 1978; B. Nitschke, Wysiedlenie ludności niemieckiej z Polski w latach 1945-1949, Wydawnictwo Adam Marszałek, Torun 2000.

10 Vide: A. Wylegała, Przesiedlenia a pamięć. Studium (nie)pamięci społecznej na przykładzie ukraińskiej Galicji i polskich "Ziem Odzyskanych", Wydawnictwo Naukowe Uniwersytetu Mikołaja Kopernika, Torun 2014, p. 141-145.

11 A. Brencz, Oswajanie niemieckiego dziedzictwa kulturowego. Z badań etnologicznych na Srodkowym Nadodrzu, in: Wokót niemieckiego dziedzictwa kulturowego na Ziemiach Pótnocnych i Zachodnich, Z. Mazur, ed., Instytut Zachodni, Poznań 1997, p. 191-216; as cited in: A. Wylegała, Przesiedlenia a pamięć..., p. 146. 
physical sense and our social understanding of the concept. The pioneering insights into this subject were brought forth by Florian Znaniecki in the 1938 article titled Socjologiczne podstawy ekologii ludzkiej (Sociological Principles of Human Ecology). The author was one of the first researchers in the world to analyze 'space' from a sociological point of view. ${ }^{12}$ Based on culture theory, he proposed the term 'spatial value,' with reference to non-spatial systems of values, such as religious, aesthetic, technical and manufacturing, economic and social. He also noticed that the public space is marked with some values. Such an approach to defining its distinguishing features established a new way of thinking about 'space' that is always related to a certain community, the members of which are entitled to remain within it. ${ }^{13}$ In turn, Martin Heidegger regarded 'dwelling, building and existence' as synonymous. According to his understanding of the German etymology of the words 'bauen' and the conjugated forms of 'sein,' for Heidegger human 'is insofar as he dwells, but also he cherishes'. ${ }^{14}$ For this German philosopher, a human being and 'space' are intertwined, the latter is neither an external object nor an inner experience'. ${ }^{15}$ The space reveals its presence and owes this to the fact that the human inhabits space, and exists within it. The relationship between a human and space is exactly the act of dwelling understood from the perspective of man's relationship to location (place) formed through the act of building. ${ }^{16}$ Elżbieta Wolicka noted the importance of the definition of 'place' by Heidegger in the creation of an identity of a given inhabitant and his history. The Lublin researcher, who, as a child was forced to leave the city of Warsaw, which was turned into ruins during the Second World War, later settled in a post-German villa in Gdańsk ${ }^{17}$ - and stated that "in order to be oneself and for self-awareness, people need a place - in the literal and symbolic sense, where they would feel 'at home,' which they could

12 F. Znaniecki, Socjologiczne podstawy ekologii ludzkiej, "Ruch Prawniczy, Ekonomiczny i Socjologiczny" 1938, no 1, p. 89-119.

13 K. Podemski, Przestrzeń publiczna w aspekcie spotecznym, in: Seminarium nt. przestrzeni publicznej. Materiat poseminaryjny 13-14 października 2008, Poznań 2008, p. 19, http:// www.poznan.pl/mim/s8a/seminarium-w-poznaniu-nt-przestrzeni-publicznej-13-14-102008,p,1025,1035,12826.html, (accessed October 10, 2015).

14 Heidegger included his reflections on this topic in the lecture titled Bauen, Wohnen, Denken, 1951. M. Heidegger, Building Dwelling Thinking, transl. A. Hofstadter, in: idem, Poetry, Language, Thought, Harper Collins Publishers, New York 2001, p. 143-159.

15 Ibid. p. 154.

16 Ibid. p. 155.

17 Her family house was destroyed during the first bombings of Warsaw in 1939. Elżbieta Wolicka spent the entire war in occupied Warsaw, in 1945, herself and her family moved to Gdańsk. Vide: A. Góra-Stępień, Elżbieta Wolicka-Wolszleger (1937-2013), [leksykon Ośrodka "Brama Grodzka - Teatr NN"], http://teatrnn.pl/leksykon/artykuly/elzbieta-wolicka-wolszleger-19372013/, (accessed May 27, 2018). 
regard as a spatial confirmation and consolidation of their own identity". ${ }^{18}$ The Western and Northern Territories, ${ }^{19}$ mainly inhabited by people deported from pre-war Poland east of the Bug River, or by those who fled the repressions of the new regime were, with difficulty, becoming a place defined by Wolicka, a space marked by 'values' and therefore 'domesticated,' which is one of the main categories of the cognition of the world. The participation of people who still felt that they were not 'at home' in those territories in creating art was meant to accelerate the elimination of such a sense of alienation. Through the prism of culture humans recognize themselves as members of a community. ${ }^{20}$

In the first difficult post-war years, former German territories taken over by the Polish administration were in the process of dynamic integration with other parts of the country in the political and economic sphere and, as noted by Konrad Schiller, nobody paid much attention to the culture and visual arts in smaller localities. ${ }^{21}$ Only in larger cities was an artistic life dynamically organized by artists - refugees from other parts of the country, very often from Poland's lost Eastern Borderlands, and attracted by the authorities with state-funded stipends and the prospects of obtaining their own flat and an atelier. ${ }^{22}$ This creative impetus was drastically impeded with the introduction of the socialist realism doctrine, during the reign of which, artist's initiatives were reduced to

18 E. Wolicka, Osobowa tożsamość i odrębność w perspektywie hermeneutyki dialogicznej, in: Tożsamość, odmienność, tolerancja a kultura pokoju, J. Kłoczowski, S. Łukasiewicz, eds., Instytut Europy Środkowo-Wschodniej, Lublin 1998, p. 46.

19 These regions are often called Ziemie Odzyskane (Recovered Territories), either capitalized: Ziemie Odzyskane or in quotation marks: „Ziemie Odzyskane” - the problematic nature of different versions of this concept in the contemporary discourse, both popular and scholarly, was outlined by Janusz Jasiński. See: J. Jasiński, Kwestia pojęcia Ziemie Odzyskane, in: Ziemie Odzyskane / Ziemie Zachodnie i Pótnocne 1945-2005 - 60 lat w granicach państwa polskiego, A. Sakson, ed., Instytut Zachodni i Muzeum Pomorza Środkowego w Słupsku, Poznań 2006 pp. 15-25; J. Jasiński, Czy powinniśmy odcinać się od pojęcia Ziemie Odzyskane, in: Echa przeszłości V, Witold Gieszczyński et al., eds., Wydawnictwo Uniwersytetu Warmińsko-Mazurskiego, Olsztyn 2004, pp. 315-320.

20 A. Giza, Kultura i samowiedza społeczna, "Kultura i rozwój” 2016, no 1 (1), p. 16.

21 K. Schiller, Awangarda na Dzikim Zachodzie. O wystawach i sympozjach Ztotego Grona w Zielonej Górze, Stowarzyszenie 40000 Malarzy i BWA Zielona Góra, Warszawa-Zielona Góra 2015, pp. 7-8.

22 For example Lublin between July 1944 and January 1945 was the seat of the central government and the city attracted many artists from across the country. However, beginning from the first months of 1945, many of the visiting artists started to leave, very often going west or north-west. For instance, Marian Tomaszewski left for Szczecin. In turn, the members of the pre-war artist group Zwornik arrived in Wrocław: Eugeniusz Geppert and Emil Krcha. For more information on the origins of the formation of artistic environments in Wrocław cf.: S. Świsłocka-Karwot, Obraz rozciagnięty w czasie. Środowisko wrocławskie i sztuka w latach 1946-2006, in: Wrocław sztuki. Sztuka i środowisko artystyczne we Wroctawiu 1946-2006, A. Saj, ed., Agencja Reklamowa i Drukarnia Kontra s.c., Wrocław 2006, pp. 289-293. 
state-controlled thematic exhibitions. ${ }^{23}$ In the period of the so-called Thaw, an innovative art form, previously overruled by social realism as an unwanted manifestation of formalism, regained popularity and, as mentioned by Wojciech Włodarczyk, "it nearly gained the required exclusivity to be a representation of the political independence of an artist and of 'progressive' views". ${ }^{24}$ In reality, the independence of artistic expression, initiated during the Thaw, had an illusory, limited character. Artists' references to the modernist paradigm with a clear anti-socialist realism intent was something the authorities were comfortable with, because these slogans were not political. On the contrary, from the artists' point of view this kind of artistic freedom was atoned for with being in a position, which Piotr Piotrowski dubbed 'pragmatic opportunism'. ${ }^{25}$

The initiators of these fully-fledged, often international, consecutive artistic meetings, organized in the western and northern areas of communist Poland in the 1960s, did not hesitate to use various forms of support from the central and local governments. In accordance with the official cultural policies of the state implemented at the time, the budget for avant-garde high art was moved to the provinces. ${ }^{26}$ This is why artists were happy to organize large events in peripheral parts of Poland, where - as recalled by Jan Berdyszak in relation to the Golden Bunch Symposia he participated in - it was easier to bring new ideas into artistic circulation in the conditions of less strict censorship and in almost closed circles. ${ }^{27}$

23 They were often 'touring exhibitions,' e.g. an exhibition under the patronage of the National Directorate of Museums of the Ministry for Culture and Art, titled Mickiewicz-Puszkin, at the turn of the years 1949 and 1950, was presented nationwide from Olsztyn (November 1949) to Oława (May 1950). Vide: A. Straszewska, coop. A. A. Szablowska, Rok 1949. Diariusz wydarzeń, in: Polskie życie artystyczne w latach 1944-1960, t. 3, Rok 1949, A. Wierzbicka, ed., Instytut Sztuki Polskiej Akademii Nauk, Warszawa 2012, p. 247. Local occasional exhibitions were also popular, for example during the autumn-winter season topics related to the life and creations of Stalin were favoured, which was due to the date of Yosif Vissarionovich's birthday - the 18th of December. For instance in Lublin the exhibition Works of Stalin and about Stalin, which was organized by the Hieronim Łopaciński Public Library, was opened in December 1950. Cf.: Prace Stalina i o Stalinie. Wystawa w Muzeum Lubelskim, "Życie Lubelskie" 1950, no 351, p. 6.

24 W. Włodarczyk, Socrealizm. Sztuka Polska w latach 1950-1954, Libella, Paris 1986, p. 117. P. Piotrowski, Znaczenia modernizmu, Rebis, Poznań 2011, p. 125.

25 E. Kowalska, Kalendarium plenerów Osieckich 1963-1981, in: Awangarda w plenerze: Osieki $i$ Łazy 1963-1981. Polska awangarda II połowy XX wieku w kolekcji Muzeum w Koszalinie,

26 J. Kalicki et al., eds., Muzeum w Koszalinie, Koszalin 2008, p. 158.

27 Przestrzeń społeczna. Historie mówione Złotego Grona i Biennale Sztuki Nowej. Rozmowa z Janem Berdyszakiem (fragment), rozmawia Marta Gendera i Piotr Słodkowski, "Szum", 3.12.2014,http://magazynszum.pl/rozmowy/przestrzen-spoleczna-historie-mowione-zlotegogrona-i-biennale-sztuki-nowej-rozmowa-z-prof-janem-berdyszakiem-fragment, (accessed October 25, 2015). The first cyclical events of en plein air and symposial character in the 1960s decade took place in 1963: the exhibition and symposium of the Golden Bunch (Zielona Góra, October 1963) or Koszalin Plein-air (Osieki, 2nd-15th September 1963). 
Also in Elblagg, an initiative by Gerard Kwiatkowski, also known by his German name Jürgen Blum, was welcomed in an environment susceptible to new ideas, ${ }^{28}$ who after obtaining permission from the city council, opened The El Gallery in the ruined post-Dominican church and monastery complex, the gallery was officially opened on the 27th of March 1962. The idea of adapting sacred buildings to serve as artistic venues was exactly in line with the official policy of society secularization, so it was, the most likely reason for its approval..$^{29}$ Only three years later, in July 1965, the First Biennale of Spatial Forms was inaugurated, this event was initiated by Gerard Kwiatkowski and artists belonging to the circle around Galeria Krzywe Koto (Crooked Wheel Gallery), with support and financial patronage from Elbląg Mechanical Factory (ZA$\mathrm{MECH}$ ), which was, at the time the largest producer of turbines and other components for the shipyard industry in Poland. About fifty artists participated in Biennale. Between 23 July and 22 August 1965, together with specialists from $\mathrm{ZAMECH}$, they produced most of the structures designed earlier, ${ }^{30}$ which were then placed on the city's avenues and squares among numerous passers-by.

The reference to the Constructivist tradition at Elblag Biennale was particularly marked by the actual implementation of the alliance between artists and workers' ${ }^{31}$ The path to the approval for the project, which Gerard Kwiatkowski and Marian Bogusz planned with grandeur, was long and complex. ${ }^{32}$ To achieve their aim, the project's authors effectively employed the rhetoric of the Russian productivist texts by Nikolai Punin and Osip Brik who drew parallels between the activities of artists and workers. ${ }^{33}$ The final result, however, depended on support from ZAMECH and the personal engagement of its workers. This unique act of participation of non-artists, enforced by the specific nature of the Biennale and formulated in detail with a list of conditions for attending the event, ${ }^{34}$ in terms of

28 It should be noted that he was born in 1930 in the pre-war Polish-German borderland in the village of Faulen (now Ulnowo).

29 J. Denisiuk, ed., Otwarta Galeria. Formy przestrzenne w Elblagu. Przewodnik / Open Gallery. Spatial Forms in Elblag. Guidebook, Centrum Sztuki Galeria EL, Elblagg 2006, p. 5.

30 The designed projects were very often altered. This was related to technical issues, but also to the approval of the style by the organizers (in this matter, it was primarily Marian Bogusz, who had the decisive word).

31 Piotr Juszkiewicz mentions three aspects of the presence of the constructivist tradition in Elblag, raised by the researchers up to the present time: personal aspect, stylistic aspect and, the one which is of interest to me - the theme of the collaboration of artists' and workers' collective, described by the Poznań art historian as 'ideological.' Vide: P. Juszkiewicz, Cień modernizmu, Wydawnictwo UAM, Poznań 2013, p. 144.

32 Its course starting from the emergence of the concept to the realization of the project was analysed by A. A. Leśniewska, Nowe miejsce rzeźby w sztuce polskiej lat 60. XX wieku jako wyraz przemian w sztuce przestrzeni, Instytut Sztuki PAN, Warszawa 2015, pp. 115-126.

33 Cf.: ibid., p. 119.

34 Cf.: M. Bogusz, ed., I Biennale Form Przestrzennych. Elblag 23.VII- 22.VIII.1965, [catalogue]. 
the construction and assembly of the art works, evolved towards an authentic engagement of both engineers and workers, who, together with the artists made the decisions regarding the constructional issues of the spatial forms produced. ${ }^{35}$

Kwiatkowski also expressed hope for the active involvement of the citizens of Elblag: "We would like the spatial forms placed in various locations in the city to form a bond with people, (...) to initiate the process of reflection. This is our understanding of the objective and sense of modern art - the impact that it has on people on a daily basis within the city space and at work" ${ }^{36}$ Such postulates remained in the sphere of utopian ideals. Spatial forms, which initially attracted significant interest from the public, who dubbed them 'Binole ${ }^{37}$ - soon ceased to cause sensation and became "a mirage that briefly created a festive atmosphere. Thereafter, the footprints of the artists were covered with dust and rust and nobody paid attention to them". ${ }^{38}$ Regardless of many crucial, albeit well-known and described details of this event, ${ }^{39}$ it is worth to focus on the relationship between the ideological correctness and artistic autonomy of the Elblagg creations. Referring to an undated document, most probably from before November 1964, Piotr Juszkiewicz attempts to challenge the heroic myth of modernity, intentionally smuggled in by the Elbląg Biennale ideologists under the slogans of collaboration between artists and workers. $\mathrm{He}$ perceived the conditions of the time rather as "people pursuing their place in a difficult post-war reality" ${ }^{40}$ working from the perspective of a provincial, ruined town, as he described it: "lit after dark with 450 gas streetlights", ${ }^{41}$ people who did not always notice the thin boundary between the ideological concept of the Polish People's Republic and the neutral modernity, whose 'thinking horizons harmonized with these ideas without collision' ${ }^{42}$ One can partly disa-

35 Claire Bishop in her extensive study devoted the participatory art, when analysing the socially-orientated participatory activities from the 1960s and 1970s in the Eastern Bloc countries (specifically based on examples from Czechoslovakia and the Soviet Union) neglects this aspect, focusing on the 'participation' understood as 'the means of mobilization of the subjective experience among the privy artists and poets and not among the wider public.' C. Bishop, Artificial Hells. Participatory Art and the Politics of Spectatorship, Verso, London-New York 2012, p. 130.

36 G. Kwiatkowski, Jesteśmy optymistami, "Polska” 1965, no 11, p. 6.

37 M. Kitowska-Łysiak, Droga sztuki, czyli elblaskie "binole", in: ead., Ślady. Szkice o sztuce polskiej po 1945 roku, Towarzystwo Naukowe KUL, Lublin 1999, pp. 71-102.

38 G. Kowalski, Spojrzenie na lata 60., in: Idee sztuki lat 60. oraz inne sesje, seminaria $i$ wystawy Centrum Rzeźby Polskiej, J. S. Wojciechowski, ed., Centrum Rzeźby Polskiej, Orońsko 1994, p. 108-109.

39 Cf.: J. Denisiuk, ed., Otwarta Galeria...; E. Dzieweczyńska, ed., W obliczu Jubileuszu 50-lecia I Biennale Form Przestrzennych w Elblagu, Centrum Sztuki Galeria EL, Elbląg 2015.

40 P. Juszkiewicz, Cień modernizmu..., p. 144.

41 Ibid., p. 141.

42 Ibid., pp. 143-144. 
gree with this thesis, considering the fact, that this perspective was broadened from Bogusz's point of view, because he was 'a player' who was experienced in communicating with the authorities, someone who was familiar with Communist Party rhetoric. This artist actively co-inspired almost all of the initiatives of a symposial and en plein air character, starting from open air events in the Pomeranian village of Osieki to the Lublin Visual Arts Meetings 1976-1979.43 At this point, it should be emphasized what great attention Bogusz paid to the social aspect of art.

The form of the Elblag spatial structure, fully abstract, was determined not only by the simple pragmatism of using scrap metal provided to artists by ZA$\mathrm{MECH}$, but is was rather a reflection of the wider scope of the trends present in contemporary sculpture. On the one hand, the attractiveness of abstract forms in the Polish art of the second half of the 1950s and in the 1960s may be explained by means of the attempt to 'compensate' for the time lost by the Polish artists in the period of enforced social realism. ${ }^{44}$ Other explanation might be, a not exactly clarified, but a sense intensified at the time, of an artistic 'desire for space' as Bożena Kowalska named this phenomenon, manifesting itself through the diffusion of boundaries between different types of art and related dynamic pursuits and transformations. ${ }^{45}$ It was about the sculpture becoming opened to space and, at the same time, about the space being ready for annexation by the sculptural structure, and pioneering considerations, and not only with regard to Polish art, as was presented by Katarzyna Kobro in her canonic book Kompozycji przestrzeni... (Composition of Space), already in 1931.46 Piotr Juszkiewicz, however, drew attention to the essence of the concept of space proposed by this Łódź-based artist and co-author of the book Władysław Strzemiński, which he perceives as 'something devoid of content, bereft of places and surroundings, lacking the meanings of closeness and distance, homeliness and distance' ${ }^{47}$ This

43 For a further description of Bogusz's work as an active inspirer and initiator of socio-artistic events, vide: B. Kowalska, Bogusz...

44 This could have been a reason for the subsequent negation of all manifestations of realism, the different types of which, were, nota bene, very popular in art that appeared in the public space of Western Europe and the USA, originating from the pop-art response of artists to the experience of mass culture and of its consumerist character (e.g. sculptures by George Segal).

45 B. Kowalska, Tęsknota do przestrzeni, in: Idee sztuki lat 60. oraz inne sesje..., pp. 11-12. Anna Maria Leśniewska devoted her recent book to the new meaning of space in the art of the 1960s; vide: A. M. Leśniewska, Nowe miejsce rzeźby....

46 K. Kobro, W. Strzemiński, Kompozycja przestrzeni. Obliczenia rytmu czasoprzestrzennego (Composition of Space. Calculations of Space-Time Rhythm), Łódź 1931. 'The communication of sculpture with space, the saturation of space with a sculpture, the merging of a sculpture with space and its connection with space - constitutes the organic law of sculpture'. Vide: id., Kompozycja przestrzeni. Obliczenia rytmu czasoprzestrzennego (fragmenty), "Sztuka i Filozofia" 1997, vol. 13, p. 88.

47 P. Juszkiewicz, Cień modernizmu..., p. 78. 
would indicate the desirability of putting the concept of Unism in the first place of some abstract order, within the undefined, non-personalized space.

The proposals of artists submitted at Visual Arts Symposium Wrocław '70, in the studies of post-war Polish art, are usually perceived in a symbolic way as the first manifestations of the conceptual art in Poland. ${ }^{48}$ In addition to numerous political patrons of this initiative, the development of the ideological guidelines involved artists from the Wrocław district of the Association of Polish Artists and Designers (ZPAP) and the artists and art critics connected with Mona Lisa Gallery, led by Jerzy Ludwiński. The event's main objectives - let us recall that it was organized within the framework of the celebration of the twenty-fifth anniversary of the 'return' of the Western and Northern Territories to the 'mother country'- were 'an attempt to confront different ways of visual arts thinking, which would eventually lead to the creation of exceptional art works within the cultural life of Wrocław city'. ${ }^{49}$ It was assumed that 'the proposed solutions will create a new spatial and urban structure of the city' ${ }^{50}$ As a matter of fact, the presented concepts were in the main to be realized with the use of durable materials, in the locations agreed with Wrocław city's architects. The scheme which was similar to the one implemented a few years back in Elbląg was expected to work in this case as well - the art forms produced by the local factories according to the submitted and accepted designs were supposed to be placed in the public space of Wrocław city. ${ }^{51}$ Eventually, the only material trace of the Symposium, which started in March, but was never officially closed (it continued until the end of 1970) were scarcely three art installations. ${ }^{52}$ There were two ephemeral projects: Kompozycja świetlna nieograniczona - 9 promieni światta na niebie (Limitless Light Composition - 9 Rays of Light in the Sky) by Henryk Stażewski, presented on the 9th of May 1970 and Wieża Radości (The

48 Cf.: B. Kowalska, Polska awangarda malarska 1945-1970. Szanse i mity, Państwowe Wydawnictwo Naukowe, Warszawa 1975, p. 137-138; A. Wojciechowski, Młode malarstwo polskie 1944-1974, Zakład Narodowy im. Ossolińskich, Wrocław-Warszawa-Kraków-Gdańsk 1975, pp. 134-136; A. Kępińska, Nowa sztuka. Sztuka polska w latach 1945-1978, Wydawnictwa Artystyczne i Filmowe, Warszawa 1981, pp. 201-203. Luiza Nader pointed out the fact that, among 57 projects presented at the exhibition at the Museum of Architecture, which accompanied the event, in fact, only in the case of just over a dozen projects, the ideas would replace the artist's actions; cf.: L. Nader, Sympozjum Wrocław '70: przestrzeń "niemożliwego", "Dyskurs", 2005/2006, vol. 3, pp. 149-150. The author was especially interested in the latter, this is why she attempted to trace the conceptual aspect of the Symposium and to evaluate its importance.

49 As cited in: D. Dziedzic, Z. Makarewicz, eds., Sympozjum Plastyczne Wrocław '70, Ośrodek Teatru Otwartego "Kalambur", Wrocław 1983, p. 176.

50 Ibid.

51 J. Bogucki, Od I-go pleneru koszalińskiego do spotkania "Wroctaw '70", in: ibid., p. 21.

52 Not including The Chair by Tadeusz Kantor, produced according to the original sketches of the artist and placed at the corner of Rzeźnicza and Nowy Świat streets only in 2011. 
Tower of Joy) by Andrzej Wojciechowski and Mieczysław Zdanowicz and also, realized in 1972, Żywy Pomnik Arena (Live Monument Arena) by Jerzy Bereś. All three projects engaged the general public - the city's inhabitants at various stages of the creation and appreciation of the art works. The work of Stażewski consisted of 9 multi-colour light rays, which were admired by the citizens of Wrocław for 1.5 hours on the city's skyline on Victory Day, a date of special importance from the point of view of Recovered Territories propaganda. ${ }^{53}$ It was planned that this ephemeral show could be repeated on the occasion of other celebrations.

The Tower of Joy, installed on 23 July 1970 on the former Dzierżyńskiego Square in the form of a 12-metre-long cone covered with masking net became a pretext for the organization of happening-like activities with participation from the local citizens and music orchestras. This unusual flower pyramid attracted crowds, as people were fascinated by the innovative project, which was - as Dorota Grubba-Thiede puts it - a farewell to the spatial layout of that particular city zone, which was soon to be transformed, and its 'participant were dancing, bringing into the city space the eternal tradition of carnival as described by Bakhtin' ${ }^{54}$ They were also direct co-creators of The Tower: on the grid, they placed flowers from the Feast of Flowers, as the communist holiday of 22 July used to be called in Wrocław. ${ }^{55}$ Using cranes, members of the public were able to arrange the bouquets even at the very top of the tower. The participation of the public was completely voluntary - the same cannot be said for other communist state ceremonies. The Tower of Joy seems like a proposal of the counterholiday to the official ceremonies marking the anniversary of the establishment of communist authority in Poland (the PKWN manifesto).

In turn, the inverted tree presented within the Arena project by Jerzy Bereś, with its branches buried in the ground, may be interpreted as a direct reference to the fate of Wrocław's citizens, who, having been 'uprooted' from their native land, were in the difficult position, recovering their lost identity. This in-

53 K. Sienkiewicz, Henryk Stażewski "9 promieni światta na niebie”, December 2010, http://culture.pl/pl/dzielo/henryk-stazewski-9-promieni-swiatla-na-niebie, (accessed October 25, 2016).

54 D. Grubba-Thiede, Czy w awangardzie istnieje archetyp? Wokót otwartych struktur geometrycznych i złożeń szablonowych w twórczości Anny Jarnuszkiewicz, Krystiana Jarnuszkiewicza, Jerzego Mizery, Marka Saretto oraz Andrzeja Wojciechowskiego, in: Paragone. Rzeźba wobec awangardy, E. Błotnicka-Mazur, L. Lameński, M. Pastwa, eds., Stowarzyszenie Historyków Sztuki - Wydawnictwo KUL, Lublin 2018, p. 306. The author also draws the attention to the act of giving the passers-by, project descriptions reproduced in several hundred copies, i.a. Tower of Joy and also on its anticipatory nature in relation to activities by Jeff Koons and Rainbow by Julita Wójcik. Ibid., p. 307.

55 Zbigniew Makarewicz recalled that the idea of repeating the activity annually on the occasion of the Feast of Flowers was not met with approval. Z. Makarewicz, Ostatni Zjazd Awangardy, in: D. Dziedzic, Z. Makarewicz, eds., Sympozjum Plastyczne Wroctaw '70..., p. 39. 
terpretation is supported by the fact that the project was implemented only two years after the symposium ended, on the initiative of the Wrocław Admirers Society (Towarzystwo Mitośników Wroctawia) with active participation from the students of the Wrocław University od Science and Technology, who carried out all of the earthwork and gardening. ${ }^{56}$

In the context of participation, there were two promising projects that were unfortunately never realized: a project by the team of Marian Bogusz for the 'Celina' estate and the Auto-theatre by Oskar Hansen. The concept of the Bogusz's team focused on the active participation of the residents of the estate in the poetry-art creation of the surrounding space: the artistic redecoration of the garage walls at Energetyczna Street, assumed that 'the community of that region should actively participate in the act of co-creation', ${ }^{57}$ and in its attitudes it was close to Hansen's Open Form theory. ${ }^{58}$ The latter constituted a natural reference point for the architect's own project for the Wrocław '70 Symposium. The Auto-theatre was supposed to be the background for 'the average, overlooked man,' which 'would put him in the center of attention, like an actor on the stage..$^{59}$ The Auto-theatre could have become an exceptional place, in which every-day phenomena, previously ignored, would be visible. The ordinary user of space would become a creator of those events: 'Auto-theatre, representing the rich variety of forms, will be determined by the character of the chosen mass-event venue'. ${ }^{60}$

In the case of some unrealized projects, it was the usual practice that their authors deliberately rejected traditional means of artistic expression and attempted to directly affect the viewer by the implementation of ideas that crossed the boundaries of art genres. In the course of the Visual Arts Symposium one of the more significant ideas turned out to be the concept of The Centre for Artistic Research (CBA) by Jerzy Ludwiński, which was an extension of his proposal for the Museum of Current Art (Muzeum Sztuki Aktualnej) from 1966. The museum was initially enthusiastically welcomed by Wrocław authorities as a potential institution that would eventually improve the prestige of the city located in the Western Territories and the concept of which was in line with the rhetoric of the official propaganda, aimed at the decentralization of Polish culture through suppressing the domination of Warsaw and Krakow. ${ }^{61}$

56 J. Bogucki, Od I-go pleneru koszalińskiego..., p. 22.

57 D. Dziedzic, Z. Makarewicz, eds., Sympozjum Plastyczne Wroctaw '70..., p. 51.

58 Cf. e.g. O. Hansen, Forma otwarta w architekturze. Sztuka wielkiej liczby, "Struktury" 1960, no 2 (9) [suppl. to "Kamena" 1960, no 23-24], pp. 7-8.

59 The description of the Auto-theatre concept by Oskar Hansen, in: D. Dziedzic, Z. Makarewicz, eds., Sympozjum Plastyczne Wroctaw '70..., p. 86.

60 Ibid.

61 T. F. de Rosset, Nowoczesny "Museion” Jerzego Ludwińskiego, “Zabytkoznawstwo i Konserwatorstwo" 2011, vol. 41, p. 169, note 10 . 
The idea of Ludwiński's Centre for Artistic Research further developed and, at the same time, exceeded the concept of the Contemporary Art Museum by stressing the importance of artistic action. ${ }^{62}$ One of the crucial aspects was also the quest for 'methods of engaging the public in the evaluation of art, in participation'. ${ }^{63}$ The latter postulate was fully realized at the Wrocław '70 symposium. In reference to Władysław Misiak's sociological study by that summarizes the Wrocław '70 symposium, Zbigniew Makarewicz pointed out the exceptional activity of Wrocław' residents, manifested at different levels. ${ }^{64}$ Based on an analysis of the opinions of the recipients, Władysław Misiak noticed the emergence of a collective aesthetic consciousness of the inhabitants; the formation of a closer link between avant-garde art and wider society, the intention of the organizers, was, in his opinion expressed as new forms of dialogue between contemporary artists with the collective experiences of the city's residents. ${ }^{65}$

\section{A troublesome legacy?}

Is post-biennale Elbląg really only 'an urban and architectural palimpsest, full of paradoxes?' This is how the city and the presence of the spatial forms are described by Karol Sienkiewicz, who was disappointed with the fiftieth anniversary of the First Biennale. ${ }^{66}$ Is the city's problem the physicality of spatial forms, which, once in place, require further intervention and care? Their sentimental value, which is seen by the cited author in their associative names given by the residents to rusting 'Binole': 'The Bison' or 'Torture Device' ${ }^{67}$ is

62 The activity of the Centre for Artistic Research 'is supposed to be orientated not towards the past, but towards the future of art, not towards collecting art pieces, but towards their creation, not towards material objects, but rather, the artistic movement'; cf.: J. Ludwiński, Epoka btękitu, Otwarta Pracownia, Kraków 2003, p. 149. The concept of the Centre for Artistic Research eventually did not gain support from the officials and, it was not realized as well as most of the ironic and critical artist's projects prepared at the symposium, that were found to be disappointing, not to say scandalous by the authorities. Ludwiński himself was forced to find another place of life and work, he had already travelled to Wrocław from Lublin in 1966, where he, initially as a new art history graduate of the Catholic University, as a critic, supported the 'Zamek' group and in 1966 he co-organized the First Symposium of Artists and Scientists in Puławy, this was critically received by the authorities.

63 As cited in: Z. Makarewicz, Ostatni Zjazd Awangardy..., p. 31.

64 Ibid.

65 Ibid., pp. 31-32. Piotr Stasiowski is sceptical about Misiak's findings, undermining the objectivity of the surveyed group, who were mainly recruited from among people interested in the symposium, and engaged in the discussions, which accompanied the event. Cf.: P. Stasiowski, Mit przestrzeni - Sympozjum Wroctaw '70, "Fort Sztuki” 2006, vol. 1, no 3, p. 30.

66 K. Sienkiewicz, Metalowy spadek, “dwutygodnik.com”, ed. 166, 08.2015, http://www.dwutygodnik.com/artykul/6085-metalowy-spadek.html?print=1, (accessed October 20, 2016).

67 Ibid. 
only one of the elements that contributes to a broader cultural context of the Elblag Biennale. This is quite valuable, because it proves the fact that the structures have been rooted in the consciousness of Elblag's residents, having a positing or negative effect. Through their presence, they have become unique 'landmarks' from Kelvin Lynch's 'mental map', ${ }^{68}$ special marks on the imaginative map that exists in the consciousness of the individual user of this space. The state of preservation of some of the structures is far from satisfactory, as well as their contemporary surroundings, which is a negation of one of the main concepts of Elblag Biennale, which postulated that 'the art works will leave the tight framework of museums and galleries and become part of our everyday life', ${ }^{69}$ a human will live and work in a world which is an integral part of an artistic image. ${ }^{70}$ Undoubtedly, physically-existing sculptures constitute cultural capital. The Elblag artistic experiment has permanently become a part of the discourse on the presence of art in the public space, and the new forms of artistic expression that arose with Polish 1960s' sculpture. ${ }^{71}$ These spatial forms were the subject of many research studies $^{72}$ and interdisciplinary polemics; it is worth noting that the project from 2013 Przebudzenie (The Awakening) by Karolina Breguła, an artist fascinated by Elblag's 'Binole,' who, together with a group of researchers representing different fields, made a specific de-construction of the structures. ${ }^{73}$

The legacy of the Wrocław '70 Symposium, as well as its earlier editions, has a primarily intellectual dimension. For Ludwiński, it was to be a laboratory of 'impossible art'. That impossibility with regard to symposium proposals was manifested by the literal absence of material output in most cases. Among the material artifacts within the space of Wrocław city, there is only a contemporary reconstruction of The Chair (2011) by Kantor, based on the original sketches and placed where the artist intended, as well as The Arena by Bereś, also fully reconstructed in 2011, the idea of which is continued by students of the Academy of Fine Arts in Wrocław, who every spring paint roots of the withered three green. The ideological reference to the concepts of the Symposium and its chief theoretician is Wrocław Contemporary Museum, established in 2011 and temporarily located in a concrete post-German bunker, which- as Sienkiewicz noted - was a sign of the attempt to redefine the city's identity. ${ }^{74}$

68 K. Lynch, The Image of the City, The MIT Press, Cambridge Massachusetts-London 1960, pp. 78-83.

69 As cited in: P. Juszkiewicz, Cień modernizmu..., p. 143.

70 Ibid.

71 J. Denisiuk, ed., Otwarta Galeria..., p. 17.

72 Cf. e.g.: note 32.

73 K. Breguła, ed., "Formy przestrzenne" jako centrum wszystkiego / "Spatial Forms" as the Centre of Everything, Fundacja Bęc Zmiana, Warszawa 2013.

74 K. Sienkiewicz, Nie ma, ale będzie, "dwutygodnik.com”, ed. 65, 09/2011, http://www.dwutygodnik.com/artykul/2606-nie-ma-ale-bedzie.html, (accessed May 28, 2017). 
In summary, the participants of Elblagg Biennale adapted their projects and realizations to suit the expectations of the communist authorities. The main propaganda-like concepts of the collaborative work of artists, ZAMECH's engineers and workers were realized when constructing and mounting the spatial forms, which attracted, at least at the beginning, a substantial interest from the residents of Elbląg.

In Wrocław - as indicated by Luiza Nader - artistic attitudes shifted from 'avant-garde optimism' to 'neo avant-garde irony' that undermined the 'laboratory analysis' of visual forms and promoted a critical attitude towards 'art work as a product of social relations' ${ }^{75}$ The projects in many cases referred to Jerzy Ludwiński's postulates of mutual interaction between creators and recipients, allowing for a certain exchange of roles. ${ }^{76}$ Both events, either in their physical or intellectual dimension, found their Heideggerian 'places' the identities of which are still being rediscovered.

\section{BIBLIOGRAPHY}

Bishop Claire (2012) Artificial Hells. Participatory Art and the Politics of Spectatorship, London-New York: Verso.

Bogusz Marian (1968) Fragment dziennika, [in:] Realizacja i propozycje [exhibition cat.], Zachęta, May 1968, Warszawa.

Bourriaud Nicolas (2012) Estetyka relacyjna, transl. Łukasz Białkowski, Kraków: MOCAK.

Breguła Karolina, ed. (2013) "Formy przestrzenne" jako centrum wszystkiego / "Spatial Forms" as the Centre of Everything, Warszawa: Fundacja Bęc Zmiana.

Brencz Andrzej (1997) Oswajanie niemieckiego dziedzictwa kulturowego. Z badań etnologicznych na Środkowym Nadodrzu, [in:] Wokót niemieckiego dziedzictwa kulturowego na Ziemiach Pótnocnych i Zachodnich, Zbigniew Mazur, ed., Poznań: Instytut Zachodni, pp. 191-216.

Brown-Saracino Japonica, ed. (2010) The Gentrification debates, New York: Routledge.

Denisiuk Jarosław, ed. (2006) Otwarta Galeria. Formy przestrzenne w Elblagu. Przewodnik / Open Gallery. Spatial Forms in Elblag. Guidebook, Elbląg: Centrum Sztuki Galeria EL.

Dziedzic Danuta, Makarewicz Zbigniew, eds. (1983) Sympozjum Plastyczne Wroctaw '70, Wrocław: Ośrodek Teatru Otwartego "Kalambur".

Dzieweczyńska Karina, ed. (2015) W obliczu Jubileuszu 50-lecia I Biennale Form Przestrzennych w Elblagu, Elbląg: Centrum Sztuki Galeria EL.

75 L. Nader, Sympozjum Wroctaw '70..., p. 183.

76 Cf.: Z. Makarewicz, Ostatni Zjazd Awangardy..., p. 28. 
Eberhardt Piotr (2010) Migracje polityczne na ziemiach polskich (1939-1950), Poznań: Instytut Zachodni.

Erbel Joanna, Żakowska Marta (2012) Sztuka w przestrzeni publicznej, [in:] Partycypacja. Przewodnik Krytyki Politycznej, Joanna Erbel, Przemysław Sadura, eds., Warszawa: Wydawnictwo Krytyki Politycznej, pp. 254-273.

Giza Anna (2016) Kultura i samowiedza społeczna, “Kultura i rozwój”, no 1 (1), pp. 12-33.

Glass Ruth (1964) London. Aspects of Change, Centre for Urban Studies, University College in London, London: MacGibbon \& Kee.

Góra-Stępień Agnieszka, Elżbieta Wolicka-Wolszleger (1937-2013), [lexicon of Ośrodek "Brama Grodzka - Teatr NN" (eng. The Grodzka Gate - NN Theatre Centre)], http://teatrnn.pl/leksykon/artykuly/elzbieta-wolicka-wolszleger-19372013/, (accessed 27 May, 2018).

Grubba-Thiede Dorota (2018) Czy w awangardzie istnieje archetyp? Wokót otwartych struktur geometrycznych i złożeń szablonowych w twórczości Anny Jarnuszkiewicz, Krystiana Jarnuszkiewicza, Jerzego Mizery, Marka Saretto oraz Andrzeja Wojciechowskiego, [in:] Paragone. Rzeźba wobec awangardy, Elżbieta Błotnicka-Mazur, Lechosław Lameński, Marcin Pastwa, eds., Lublin: Stowarzyszenie Historyków Sztuki - Wydawnictwo KUL, pp. 293-319.

Hansen Oskar (1960), Forma otwarta w architekturze. Sztuka wielkiej liczby, "Struktury”, no 2 (9) [suppl. to "Kamena" 1960, no 23-24], pp. 7-8.

Heidegger Martin (2001) Building Dwelling Thinking, transl. A. Hofstadter, [in]: idem, Poetry, Language, Thought, New York: HarperCollins Publishers, pp. 143-159.

Hejger Maciej (2008) Przeksztatcenia narodowościowe na ziemiach Zachodnich i Pótnocnych Polski w latach 1945-1959, Słupsk: Wydawnictwo Naukowe Akademii Pomorskiej.

Jasiński Janusz (2004) Czy powinniśmy odcinać się od pojęcia Ziemie Odzyskane, [in:] Echa przesztości $V$, Witold Gieszczyński et al., eds., Olsztyn: Wydawnictwo Uniwersytetu Warmińsko-Mazurskiego, pp. 315-320.

Jasiński Janusz (2006) Kwestia pojęcia Ziemie Odzyskane, [in:] Ziemie Odzyskane / Ziemie Zachodnie i Pótnocne 1945-2005 - 60 lat w granicach państwa polskiego, Andrzej Sakson, ed., Poznań: Instytut Zachodni - Muzeum Pomorza Środkowego w Słupsku, pp. 15-25.

Juszkiewicz Piotr (2013) Cień modernizmu, Poznań: Wydawnictwo UAM.

Kacprzak Paweł (2010) Działania organów administracji państwowej w akcji wysiedlenia $i$ wyjazdach ludności niemieckiej z Polski w 1945 roku, "Studia Lubuskie”, vol. 6, pp. 87-108.

Kamiński Ireneusz J. (1979) Lubelskie Spotkania Plastyczne, Lublin: Krajowa Agencja Wydawnicza.

Kępińska Alicja (1981) Nowa sztuka. Sztuka polska w latach 1945-1978, Warszawa: Wydawnictwa Artystyczne i Filmowe. 
Kitowska-Łysiak Małgorzata (1999), Droga sztuki, czyli elblaskie “binole”, [in:] ead., Ślady. Szkice o sztuce polskiej po 1945 roku, Lublin: Towarzystwo Naukowe KUL, pp. 71-102.

Kluszczyński Ryszard W. (2010) Sztuka interaktywna. Od dzieła-instrumentu do interaktywnego spektaklu, Warszawa: Wydawnictwa Akademickie i Profesjonalne.

Kobro Katarzyna, Strzemiński Władysław (1997) Kompozycja przestrzeni. Obliczenia rytmu czasoprzestrzennego (fragmenty), "Sztuka i Filozofia", vol. 13, pp. 88-99.

Kowalska Bożena (1975) Polska awangarda malarska 1945-1970. Szanse i mity, Warszawa: Państwowe Wydawnictwo Naukowe.

Kowalska Bożena (1994) Tęsknota do przestrzeni, [in:] Idee sztuki lat 60. oraz inne sesje, seminaria i wystawy Centrum Rzeźby Polskiej, Jan Stanisław Wojciechowski, ed., Orońsko: Centrum Rzeźby Polskiej, pp. 11-16.

Kowalska Bożena (2007) Bogusz - artysta i animator, Pleszew: Muzeum Regionalne w Pleszewie

- Pleszewskie Towarzystwo Kulturalne.

Kowalska Ewa (2008) Kalendarium plenerów Osieckich 1963-1981, [in:] Awangarda w plenerze: Osieki i Łazy 1963-1981. Polska awangarda II połowy XX wieku w kolekcji Muzeum w Koszalinie, Jerzy Kalicki et al., eds., Koszalin: Muzeum w Koszalinie, pp. 156-319.

Kowalski Grzegorz (1994) Spojrzenie na lata 60., [in:] Idee sztuki lat 60. oraz inne sesje, seminaria i wystawy Centrum Rzeźby Polskiej, Jan Stanisław Wojciechowski, ed., Orońsko: Centrum Rzeźby Polskiej, pp. 105-112.

Kwiatkowski G[erard] (1965) Jesteśmy optymistami, "Polska”, no 11, pp. 5-6.

Leśniewska Anna Maria (2006) Puławy 66. I Sympozjum Artystów Plastyków i Naukowców 2-23 sierpnia 1966, Puławy: Towarzystwo Przyjaciół Puław.

Leśniewska Anna Maria (2015) Nowe miejsce rzeźby w sztuce polskiej lat 60. XX wieku jako wyraz przemian w sztuce przestrzeni, Warszawa: Instytut Sztuki PAN.

Ludwiński Jerzy (2003) Epoka btękitu, Kraków: Otwarta Pracownia.

Lynch Kevin (1960) The Image of the City, Cambridge Massachusetts-London: The MIT Press.

Magierska Anna (1978) Ziemie zachodnie i pótnocne w 1945 roku. Kształtowanie się podstaw polityki integracyjnej państwa polskiego, Warszawa: Książka i Wiedza.

Nader Luiza (2005/2006) Sympozjum Wroctaw '70: przestrzeń "niemożliwego”, “Dyskurs”, vol. 3, pp. 148-189.

Nitschke Bernadetta (2000) Wysiedlenie ludności niemieckiej z Polski w latach 1945-1949, Toruń: Wydawnictwo Adam Marszałek.

Pazik Aneta (2013) Migracje przymusowe jako instrument konsolidacji państwa narodowego w XX wieku. Przypadek wysiedleń Niemców z Polski po II wojnie światowej, "Kultura i Polityka”, vol. 13, pp. 131-152. 
Podemski Krzysztof (2008) Przestrzeń publiczna w aspekcie społecznym, [in:] Seminarium nt. przestrzeni publicznej. Materiat poseminaryjny 13-14 października 2008, Poznań, p. 19, http://www.poznan.pl/mim/s8a/seminarium-w-poznaniu-nt-przestrzeni-publicznej-13-14-102008,p,1025,1035,12826.html, (accessed October 10, 2015).

Piotrowski Piotr (2011) Znaczenia modernizmu, Poznań: Rebis.

(1950) Prace Stalina. Wystawa w Muzeum Lubelskim, “Życie Lubelskie”, no 351, p. 6.

(2014)Przestrzeńspołeczna.HistoriemówioneZłotegoGronaiBiennaleSztukiNowej.RozmowazJanem Berdyszakiem (fragment), rozmawia Marta Gendera i Piotr Stodkowski, “Szum”, December 3, 2014, http://magazynszum.pl/rozmowy/przestrzen-spoleczna-historie-mowione-zlotego-grona-i-biennale-sztuki-nowej-rozmowa-z-prof-janem-berdyszakiem-fragment, (accessed October 25, 2015).

de Rosset Tomasz F. (2011) Nowoczesny "Museion" Jerzego Ludwińskiego, "Zabytkoznawstwo i Konserwatorstwo”, vol. 41, pp. 165-183.

Schiller Konrad (2015) Awangarda na Dzikim Zachodzie. O wystawach i sympozjach Złotego Grona w Zielonej Górze, Warszawa-Zielona Góra: Stowarzyszenie 40000 Malarzy - BWA Zielona Góra.

Sienkiewicz Karol (2010) Henryk Stażewski “9 promieni światta na niebie”, December 2010, http://culture.pl/pl/dzielo/henryk-stazewski-9-promieni-swiatla-na-niebie, (accessed October 25, 2016).

Sienkiewicz Karol (2011) Nie ma, ale będzie, “dwutygodnik.com”, ed. 65, 09/2011, http://www. dwutygodnik.com/artykul/2606-nie-ma-ale-bedzie.html, (accessed May 28, 2017).

Sienkiewicz Karol (2015) Metalowy spadek, “dwutygodnik.com”, ed. 166, 08/2015, http://www. dwutygodnik.com/artykul/6085-metalowy-spadek.html?print=1, (accessed October 20, 2016).

Stasiowski Piotr (2006) Mit przestrzeni - Sympozjum Wroctaw '70, “Fort Sztuki” 2006, vol. 1, nr 3, pp. 30-31.

Straszewska Anna, coop. Szablowska Anna A. (2012) Rok 1949. Diariusz wydarzeń, [in:] Polskie życie artystyczne w latach 1944-1960, vol. 3, Rok 1949, Anna Wierzbicka, ed., Warszawa: Instytut Sztuki Polskiej Akademii Nauk, pp. 11-282.

Świsłocka-Karwot Sylwia (2006) Obraz rozciagnięty w czasie. Środowisko wrocławskie i sztuka w latach 1946-2006, [in:] Wrocław sztuki. Sztuka i środowisko artystyczne we Wrocławiu 1946-2006, Andrzej Saj, ed., Wrocław: Agencja Reklamowa i Drukarnia Kontra s.c., pp. 289-315.

Taborska Halina (1996) Wspótczesna sztuka publiczna, Warszawa: Wiedza i Życie.

Włodarczyk Wojciech (1986) Socrealizm. Sztuka Polska w latach 1950-1954, Paris: Libella.

Wojciechowski Aleksander (1975) Młode malarstwo polskie 1944-1974, Wrocław-WarszawaKraków-Gdańsk: Zakład Narodowy im. Ossolińskich.

Wolicka Elżbieta (1998) Osobowa tożsamość i odrębność w perspektywie hermeneutyki dialogicznej, [in:] Tożsamość, odmienność, tolerancja a kultura pokoju, Jerzy Kłoczowski, Sławomir Łukasiewicz, eds., Lublin: Instytut Europy Środkowo-Wschodniej, pp. 45-49. 
Wylegała Anna (2014) Przesiedlenia a pamięć. Studium (nie)pamięci społecznej na przykładzie ukraińskiej Galicji i polskich "Ziem Odzyskanych", Toruń: Wydawnictwo Naukowe Uniwersytetu Mikołaja Kopernika.

Zarycki Tomasz (2009) Kapitat Kulturowy - założenia i perspektywy zastosowań teorii Pierre'a Bourdieu, "Psychologia Społeczna", vol. 4, no 1-2, pp. 12-25.

Znaniecki Florian (1938) Socjologiczne podstawy ekologii ludzkiej, "Ruch Prawniczy, Ekonomiczny i Socjologiczny", no 1, pp. 89-119.

\section{OSWAJANIE PRZESTRZENI ZIEM ODZYSKANYCH. ASPEKTY PARTYCYPACYJNE BIENNALE FORM PRZESTRZENNYCH W ELBLĄGU I SYMPOZJUM PLASTYCZNEGO WROCŁAW '70 (streszczenie)}

W niniejszym artykule przeanalizowano kilka wątków dotyczących tytułowych wydarzeń artystycznych, ze szczególnym uwzględnieniem działań lub projektów artystów włączających aktywnie zwykłych ludzi - mieszkańców zasiedlonych po 1945 roku Ziem Zachodnich i Północnych - w proces współtworzenia / odbioru dzieła. Została podjęta próba odpowiedzi na następujące pytania: na ile omawiane plenery i sympozja w rzeczywisty sposób realizowały idee propagowane przez władzę ludową? A może odczytywane z dzisiejszej perspektywy dzieła, świadomie w zamyśle autorów ingerujące w przestrzeń publiczną, ostatecznie „wygrały” z pustą dialektyką komunistyczną, tworząc dobra, które Pierre Bourdieu włączyłby w zakres uprzedmiotowionej formy kapitału kulturowego? Czy rzeczywiście przyczyniły się do „oswojenia” terenów północnych i zachodnich, na których zorganizowano omawiane imprezy? Ponadto last but not least: pytanie o naturę owej partycypacyjności - jaki charakter miał udział poszczególnych uczestników przy współtworzeniu projektów i realizacji?

Słowa kluczowe: partycypacja w sztuce, sztuka w przestrzeni publicznej, Biennale Form Przestrzennych w Elblaggu, Sympozjum Wrocław '70, sztuka Ziem Zachodnich i Północnych 


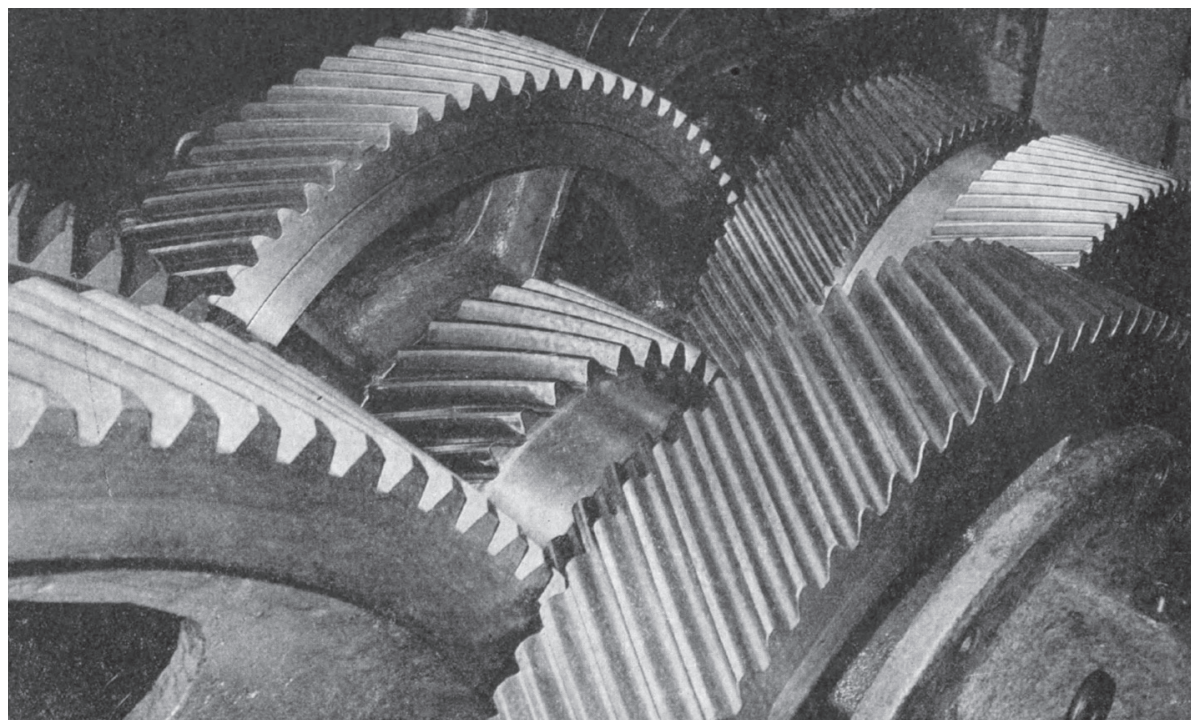

A gear (fragm.), fragment of the photo after: I. biennale form przestrzennych, Elblag 23.VII-22.VIII.1965, [catalogue], ed. Marian Bogusz

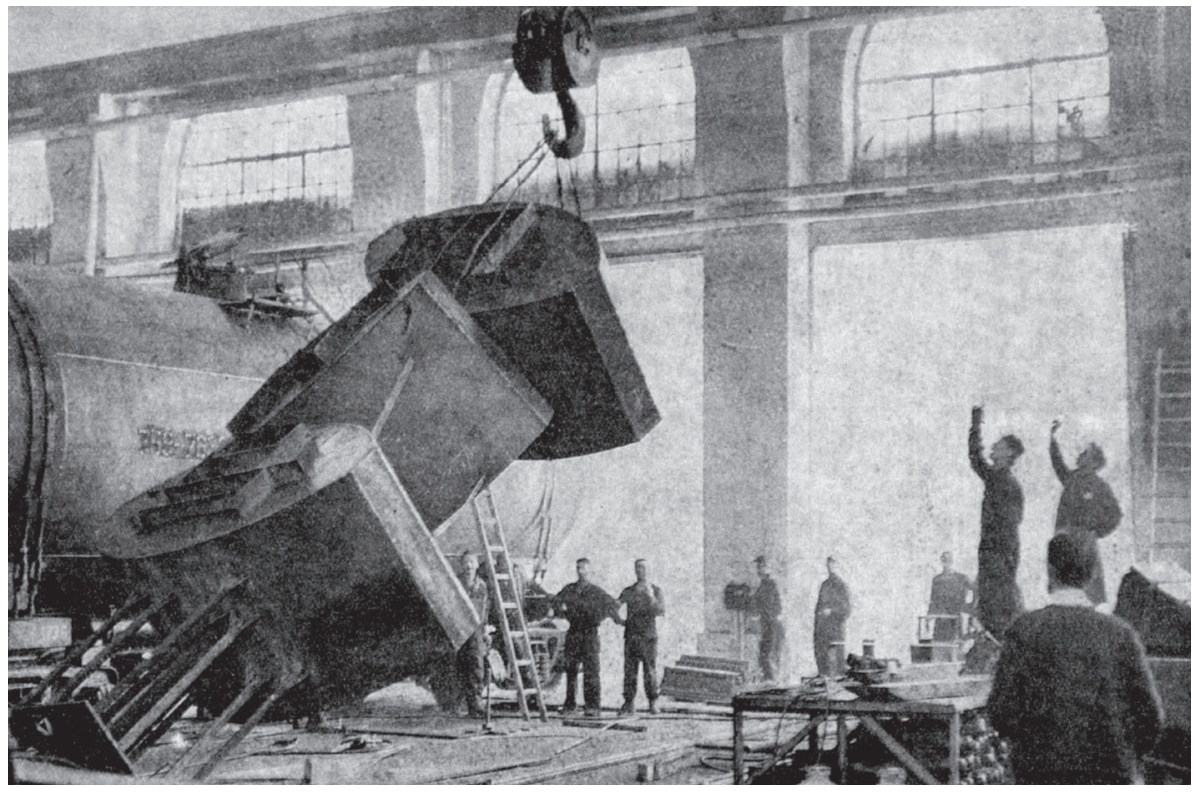

Installation of Andrzej Matuszewski's form during Elbląg Biennale, 1965, fragment of the photo after: I. biennale form przestrzennych, Elblag 23.VII-22.VIII.1965, [catalogue], ed. Marian Bogusz 


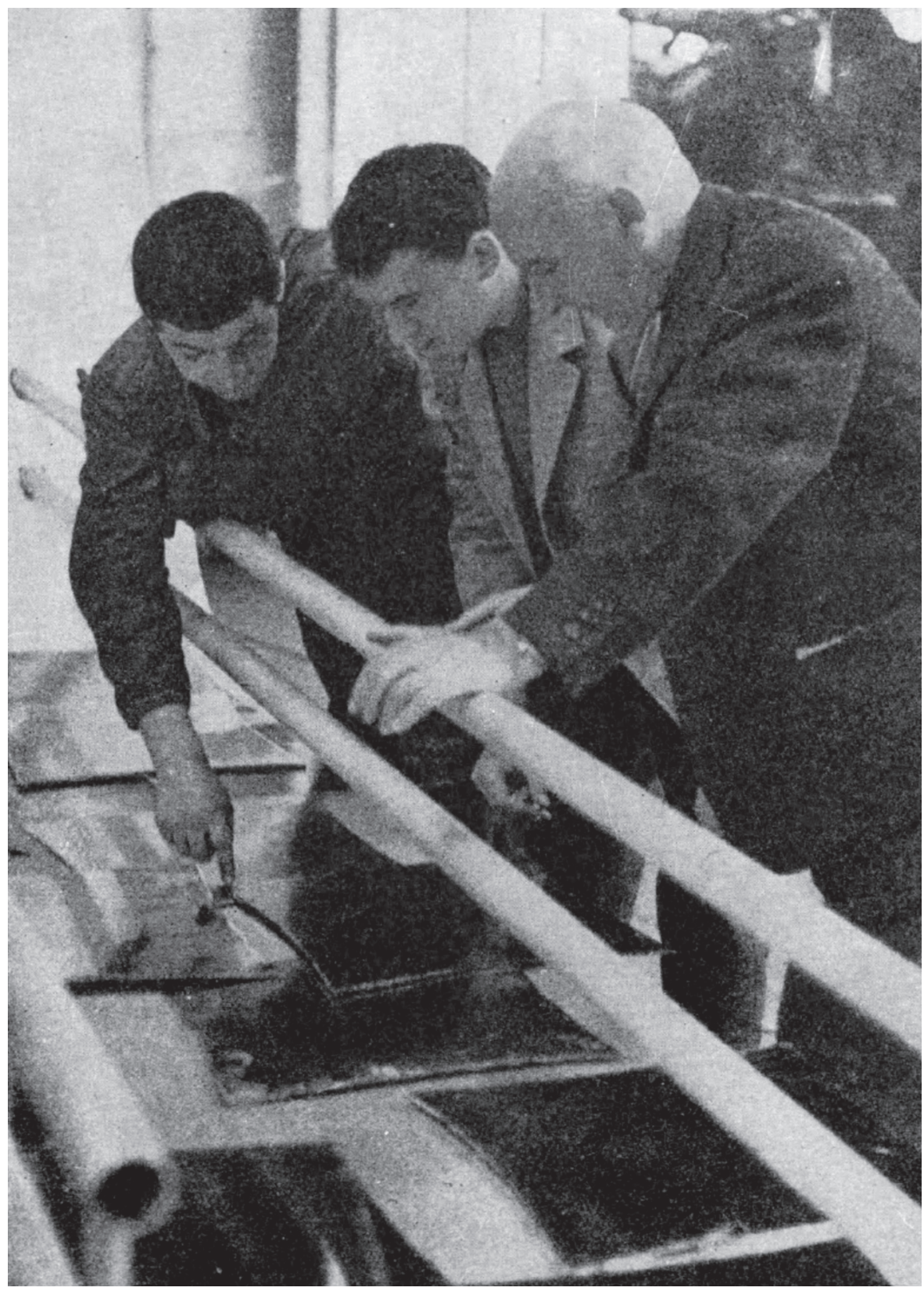

Installation of Henryk Stażewski’s form during Elbląg Biennale, 1965, fragment of the photo after: I. biennale form przestrzennych, Elblag 23.VII-22.VIII.1965, [catalogue], ed. Marian Bogusz 


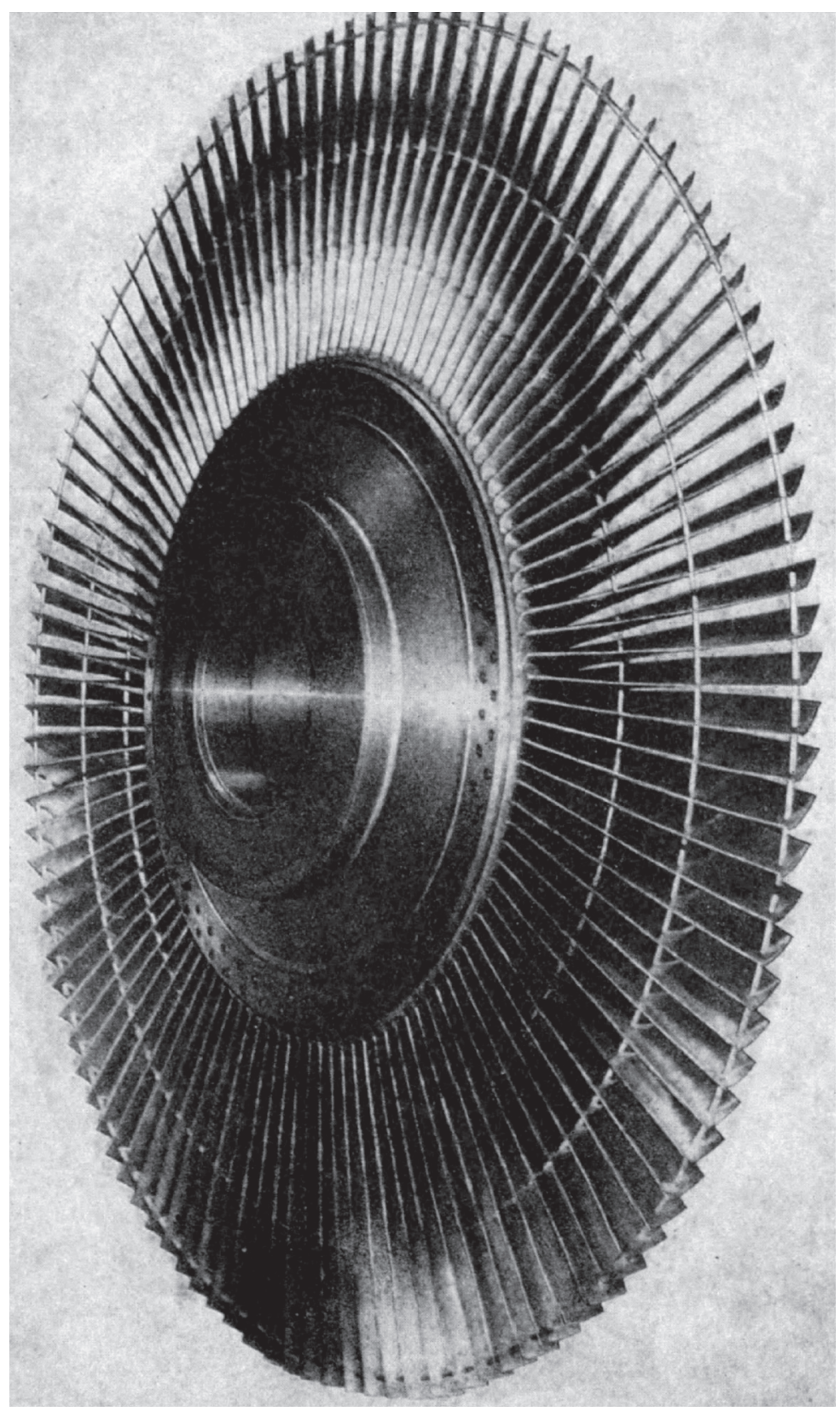

Roto disk of the turbine, fragment of the photo after: I. biennale form przestrzennych, Elblag 23.VII-22.VIII.1965, [catalogue], ed. Marian Bogusz 


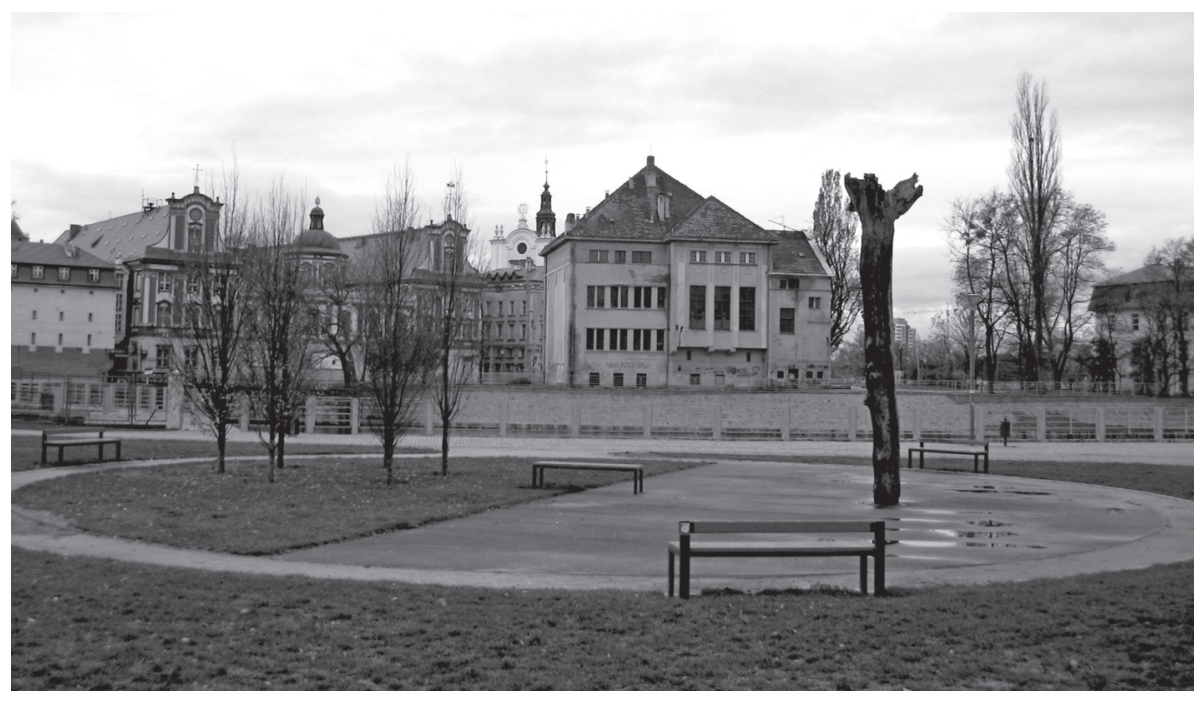

Jerzy Bereś, Żywy Pomnik Arena (Live Monument Arena), Wrocław, photo by E. Błotnicka-Mazur

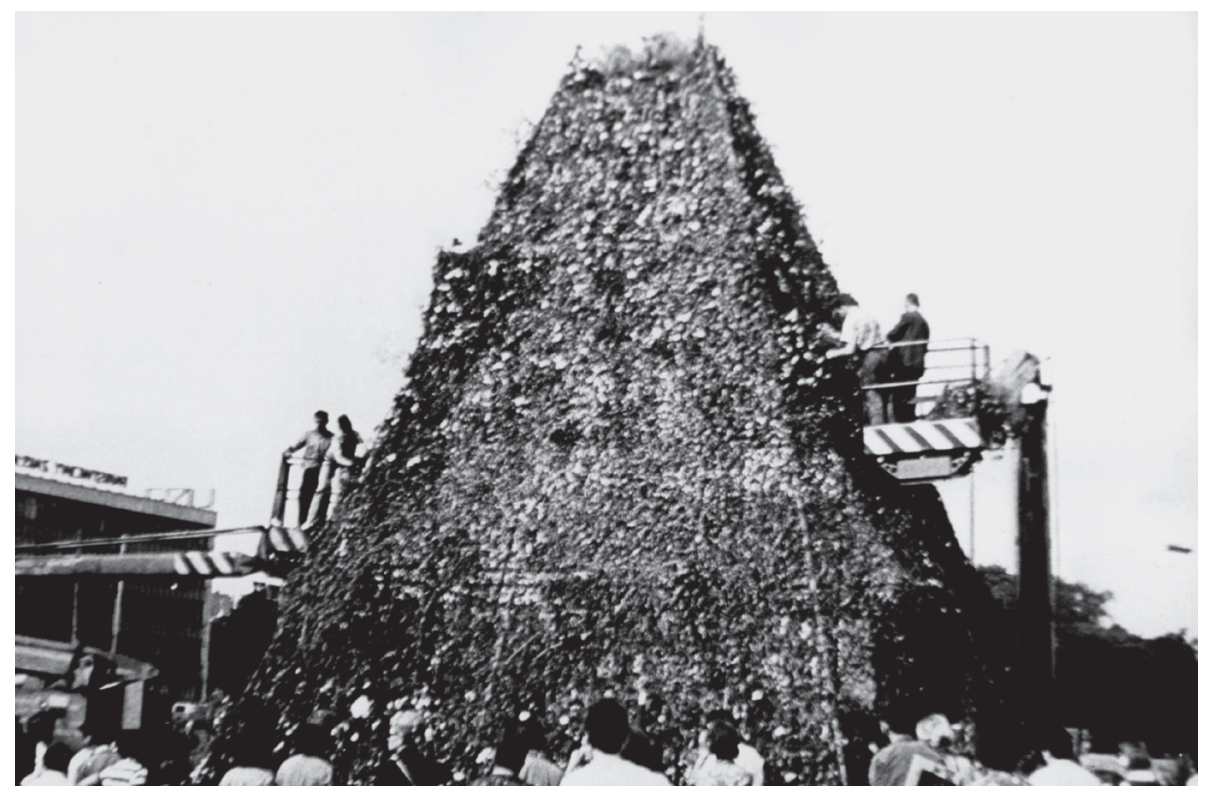

Andrzej Wojciechowski with coop. of Mieczysław Zdanowicz, Wieża radości (The Tower of Joy), Visual Arts Symposium Wrocław '70, photo courtesy of Andrzej Wojciechowski 


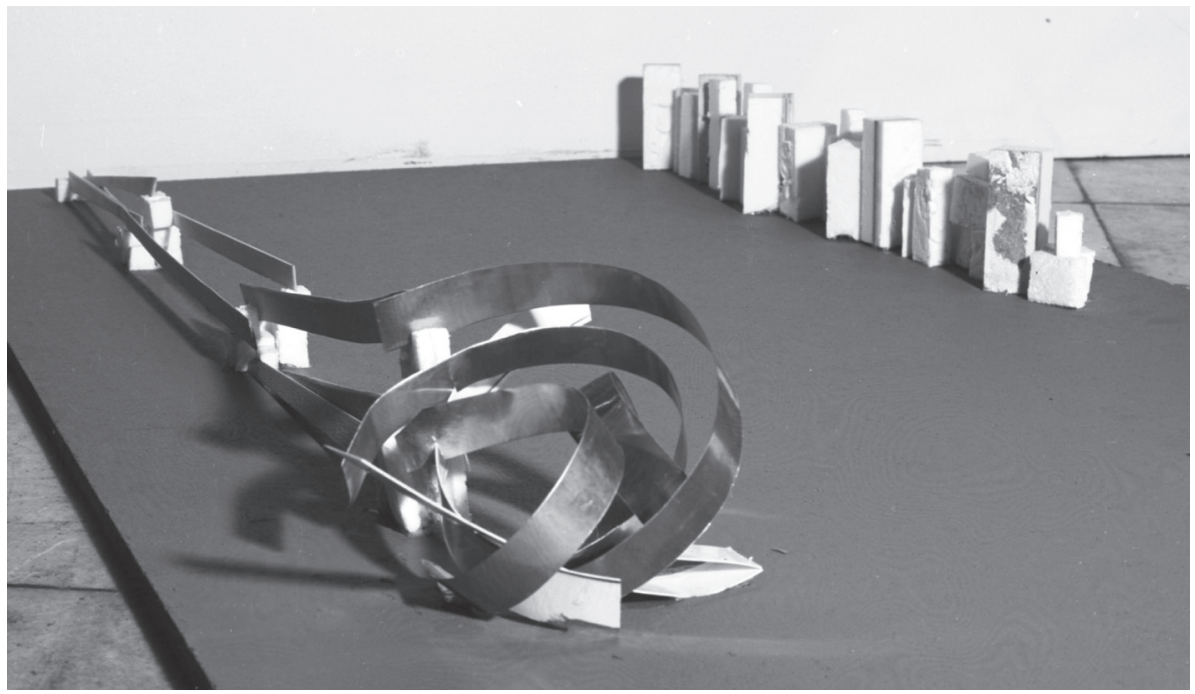

Marian Bogusz with coop. of Krzysztof Corolian and Henryk Gała, a scale model of spatial form („Celina” Estate), Visual Arts Symposium Wrocław ‘70, photo by Michał Diament, courtesy of Wrocław Contemporary Museum

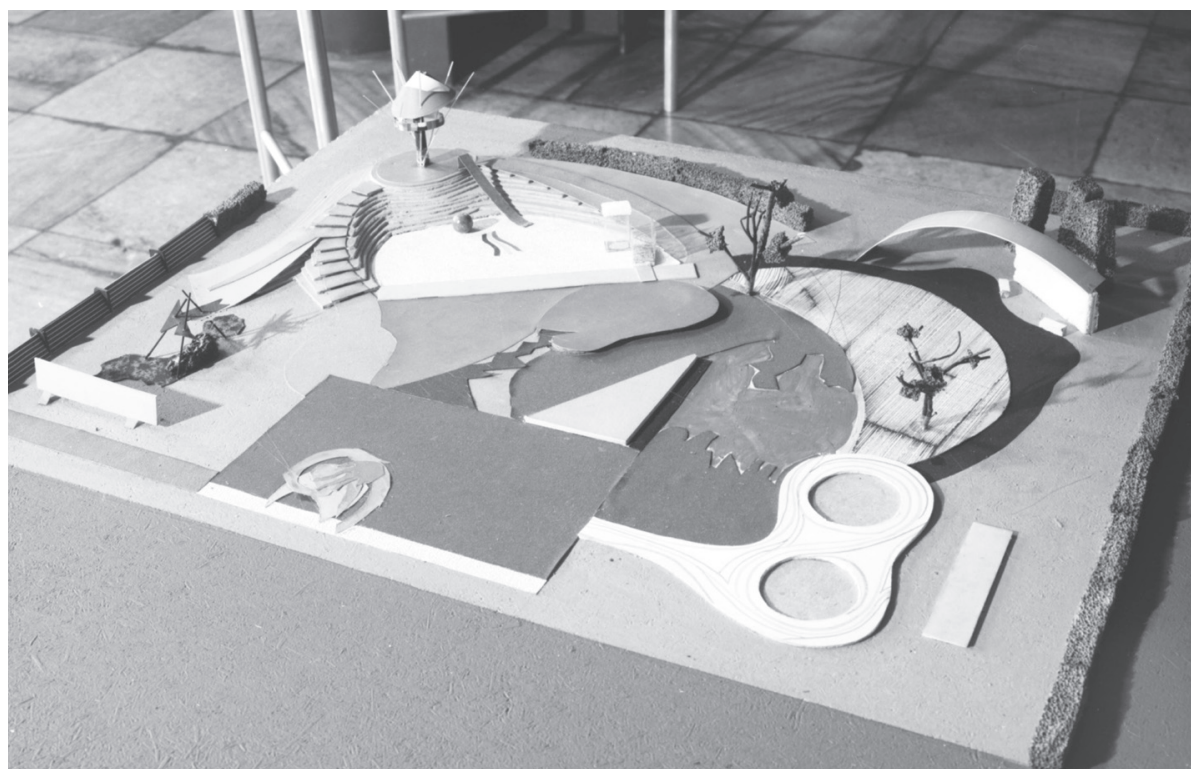

Marian Bogusz team: Andrzej Bartyński, Krzysztof Corolian, Roman Nyga, a scale model of „Celina” Estate, Visual Arts Symposium Wrocław '70, photo by Zdzisław Holuka, courtesy of Zachęta Lower Silesian Fine Arts Association 